\title{
Skin Tightening
}

\author{
Kevin R. Kwan, BA; Zachary Kolansky, MS; Brian J. Abittan, MD; Aaron S. Farberg, MD; \\ Gary Goldenberg, MD
}

\section{PRACTICE POINTS}

- There are a multitude of noninvasive modalities available to treat skin laxity.

- Understanding the mechanisms of each modality is crucial to selecting the appropriate treatment for your patients.

- Treatments should be tailored to the individual patient based on desired outcome, possible adverse events, patient preferences, and cost.

There are many undesirable manifestations that arise as one ages. One of the most notable undesired effects is increasing skin laxity. Traditionally, the gold standard of treatment is surgical correction of skin laxity. However, demand for noninvasive aesthetic procedures has grown due to minimal risk and accelerated recovery time. Over the years, many new devices have become available for addressing skin laxity including laser therapy, radiofrequency (RF), ultrasound, and intense pulsed light (IPL). This article discusses these various noninvasive treatment options and seeks to give providers details of the science behind each device.

Cutis. 2020;106:134-137, 139.

M inimally and noninvasive skin tightening has become one of the most requested cosmetic procedures. Skin laxity often is apparent in areas of the face, neck, jawline, hands, abdomen, and thighs, with features of fine lines, wrinkles, and cellulite. Intrinsic and extrinsic factors contribute to the development of skin laxity. Intrinsic aspects include chronological age, stress, and genetics, whereas extrinsic influences include exposure to solar radiation, environmental toxins, and smoking. .,2 $^{1,2}$ These factors affect the production and maintenance of both collagen and elastic proteins, which are the main components that help the skin stay firm and smooth. With a goal of improving skin laxity, multiple skin tightening modalities have been developed.

Traditionally, skin laxity was treated by invasive surgical skin procedures (eg, rhytidectomy), which carry a high financial cost, require an operating room and general anesthesia, have a prolonged recovery time with notable postoperative care, and have possible risk of unwanted scars. ${ }^{3,4}$ The risks associated with invasive procedures have spurned a growing demand for minimally invasive and noninvasive methods, which have fostered the development of several skin laxity reversal modalities over the last decade. Although the achieved results of these technologies are less dramatic and require more treatments, they do not possess the associated risks and adverse effects seen in invasive surgical procedures. As such, demand for these techniques has been growing among cosmetic patients.

There are multiple technologies that currently are employed to achieve noninvasive skin tightening. Laser therapy, radiofrequency (RF), ultrasound, and intense pulsed light (IPL) are methods that focus targeted energy to elevate temperatures in the deeper layers of the skin. Elevated thermal energy causes denaturing of collagen with preservation of heat-stable intermolecular cross-links. Skin tightening is achieved through physical shortening of the collagen fibers with preservation of the heat-stable intermolecular hydrogen bonds, which leads to an increase in the rubber elastic properties of the collagen polymer and stimulation of new collagen formation., 5 The temperature at which this process occurs has been frequently reported as approximately $65^{\circ} \mathrm{C},{ }^{7,8}$ Alternative noninvasive therapies that do not focus on elevated thermal energy for skin tightening include chemical peels and skin care products.

Given the multitude of treatment methods that have been developed to counteract skin laxity, this article seeks to provide an overview of some technologies, devices, and

\footnotetext{
Mr. Kwan is from the University of Louisville School of Medicine, Kentucky. Mr. Kolansky and Dr. Abittan are from the Icahn School of Medicine at Mount Sinai, New York, New York. Dr. Farberg is from Baylor University Medical Center, Dallas, Texas. Dr. Goldenberg is from Goldenberg Dermatology, PC, New York.

The authors report no conflict of interest.

The eTable is available in the Appendix online at www.mdedge.com/dermatology.

Correspondence: Gary Goldenberg, MD, Goldenberg Dermatology, PC, 14 E 75th St, New York, NY 10021 (garygoldenbergmd@gmail.com). doi:10.12788/cutis.0073
} 
commonly used therapies to help dermatologists choose the appropriate modalities for their cosmetic patients.

\section{Laser Therapy}

Since its approval in the 1980s, laser therapy has become an alternative to invasive surgical skin tightening. ${ }^{9}$ Laser therapy utilized for treatment can be subcategorized into 2 types: ablative and nonablative.

Traditional ablative skin tightening utilized $\mathrm{CO}_{2}$ or erbium:YAG lasers. These lasers caused skin tightening by first ablating the epidermis cleanly off the dermis, with a partially coagulated area in the dermis, which triggered a wound-healing cascade followed by neocollagenesis and remodeling. ${ }^{10,11}$ Although this treatment displays notable retightening of the skin, traditional ablative lasers are not routinely used, likely because of lengthy recovery periods, risk for scar development, flares of acne and herpes simplex virus, hyperpigmentation, and delayed-onset hypopigmentation. ${ }^{9,12,13}$

Fractional ablative laser treatments soon emerged as an effective alternative to traditional ablative lasers. Various studies have noted better recovery times and side-effect profiles. ${ }^{14-18}$ This improvement is believed to be due to the method of wound healing in fractional ablative laser treatments. Ablative fractional photothermolysis works by generating deeply narrow focal ablations that involve the dermis and epidermis while leaving the surrounding skin unscathed, which allows for rapid re-epithelization, filling in of the dermal pockets, and stimulation of dermal remodeling. ${ }^{10,11,18,19}$ Studies have demonstrated a range of improvement in skin laxity from $56 \%$ to $65.3 \%$ at 6 months posttreatment. ${ }^{20,21}$ Although the incidence of reported side effects is better than with the traditional ablative laser, fractional ablative lasers have documented reports of similar types of side effects as traditional lasers due in part to ablation of the skin..$^{22,23}$

Nonablative lasers were developed as alternatives to ablative laser treatments. This class of lasers produces a milder effect compared with its ablative counterpart. Studies show a quantitative improvement range of $8.9 \%$ to $11 \%$ in skin laxity 3 months posttreatment. ${ }^{24,25}$ Nonablative lasers induce controlled tissue injury in the dermis, which leads to stimulation of dermal remodeling and collagen production. ${ }^{11}$ Although the effects of nonablative lasers are milder compared with their ablative counterparts, they possess the superior benefit of minimal adverse events. Most studies reported transient erythema posttreatment, but no long-term adverse effects have been noted, ${ }^{26-31}$ in part due to preservation of the epidermal layer.

\section{Radiofrequency}

Radiofrequency technology was the first method marketed for noninvasive skin tightening. Radiofrequency devices work by generating heat through tissue resistance to an applied alternating electrical current, which leads to collagen contraction and remodeling along with neocollgenesis. ${ }^{32}$ The major electrode configurations used in these technologies are monopolar, bipolar, and multipolar, which differ by the electric field they produce. Reported side effects include erythema that arose 1 week following completion of treatment and resolved by 6-month follow-up, as well as hypertrophic scarring, transient postinflammatory hyperpigmentation, and pain. ${ }^{33,34}$

Monopolar systems were the first among these devices to be developed for use in skin tightening and remain the most extensively studied technology for treatment of skin laxity. Developed in 2001, the Thermage device (Solta Medical, Valent Pharmaceuticals) remains the most extensively studied technology for the treatment of skin laxity. ${ }^{35}$ In a trial performed by Fitzpatrick et $\mathrm{al}^{36}$ treatment of skin laxity of the periorbital area with ThermaCool TC (Thermage, Inc) demonstrated an $83.2 \%$ improvement in at least 1 point treated and an overall $28.9 \%$ improvement of the entire treatment area at 6-month follow-up. Additionally, a survey study of 5700 patients who received monopolar RF skin tightening treatments demonstrated that $26 \%$ of patients experienced immediate tightening following treatment, and $54 \%$ observed tightening 6 months posttreatment. ${ }^{37}$

Bipolar and multipolar devices were developed following the success of monopolar devices in the treatment for skin laxity. In a study evaluating multipolar RF for the face and neck, all 11 patients were determined to have improvement of their skin laxity following weekly treatments for 8 weeks. ${ }^{38}$

\section{Ultrasound}

The use of ultrasound for skin tightening was first approved in 2009. ${ }^{39}$ The primary mechanism of skin tightening is through thermally induced contraction of collagen with subsequent collagen neogenesis achieved through absorption of the vibrational acoustic energy into target tissue. ${ }^{40}$ There are 2 types of ultrasound methods: microfocused and high-intensity focused. Microfocused ultrasound focuses on delivering lower-energy pulses to the deep reticular dermal and subdermal layers that lead to disruption of the underlying architecture of the skin, promoting increases in distensibility, elasticity, and viscoelasticity. ${ }^{41}$ To date, microfocused ultrasound is approved for treating skin laxity of the eyebrow and submental area and wrinkles of the décolleté. Currently, there are 2 devices approved by the US Food and Drug Administration for the treatment of skin laxity with ultrasound. These devices are the Ulthera System (Merz Pharmaceuticals) and the Sofwave system (Sofwave Medical Ltd). ${ }^{42}$ Oni et $\mathrm{al}^{43}$ evaluated 93 patients following treatment using Ulthera for skin laxity in the lower face. There was a noticeable improvement of $63.6 \%$ at 90 days following treatment. Brobst et $\mathrm{a}^{44}$ showed improvement in laxity at 6 months and 1.5 years following last treatment. The most commonly reported posttreatment side effects include transient purpura, transient edema, and transient postinflammatory pigmentation. ${ }^{42,45}$ Serious complications are 
rare and include development of palpable subcutaneous nodules and motor nerve paresis. ${ }^{22,46}$

High-intensity focused ultrasound has been more recently introduced as a modality for skin tightening and rejuvenation. This method focuses on applying heat to areas through acoustic energy to areas of the deep dermis, subdermal connective tissue, and fibromuscular layer in targeted microcoagulation zones without effect to the epidermis. ${ }^{47}$ The targeted thermal effects and microcoagulation are believed to cause skin tightening through collagen contraction and remodeling. Future studies are needed to determine the overall benefits in skin laxity to achieve approval by the US Food and Drug Administration for use as a treatment option.

\section{IPL Therapy}

Intense pulsed light therapy is different from lasers in that it utilizes a wider variety of wavelengths ranging from approximately 500 to $1200 \mathrm{~nm} .^{48}$ The process of skin tightening is achieved through selective photothermolysis in which thermal damage is focused solely on pigmented targets at the cellular or tissue levels in the epidermis and dermis. ${ }^{49}$ Intense pulsed light penetrates the tissues and is selectively absorbed by melanin and hemoglobin, thereby producing photothermal effects. The photothermal effects lead to reversible thermal damage to surrounding collagen and induction contraction of collagen fibers and fiber remodeling. ${ }^{50}$ Clinical studies on the effectiveness on skin tightening have shown incongruent results. Multiple studies have noted improvement in skin elasticity as well as increased deposits of collagen in treated areas. Other studies have shown no improvement of rhytides or wrinkle reduction. The side effects noted were transient pain, swelling, and erythema, along with rare instances of blisters and crusting. ${ }^{48,51-54}$ Due to the inhomogeneous results, the use of IPL is largely reserved for treatment of acne, hyperpigmentation, hypertrichosis, and superficial vascular malformations.

\section{Chemical Peels}

Chemical peels are used in the treatment of skin laxity through a process similar to ablative lasers. Unlike other methods described in this article, this type of treatment is only reserved for the facial areas. The peel must penetrate to the lower papillary dermis or deeper to allow for adequate collagen synthesis. ${ }^{55}$ As such, medium to deep peeling agents should be used. ${ }^{56}$ Peels cause coagulation of membrane proteins and necrosis of the epidermis and dermis, thereby stimulating collagen synthesis and keratinocyte regeneration. Additionally, there is an increase in the deposition of glycosaminoglycans, which play a major role in providing hydration for the skin because of their water-binding capacity. ${ }^{56}$ Deep peels have the added effect of restoring dermal architecture to its native state. Medium-depth peels work up to the layer of the epidermis and dermis. ${ }^{57}$ Trichloroacetic acid (TCA) 35\% is the main ingredient used in these types of peels. Some examples include Monet combination (Jessner solution with 35\% TCA), Brody combination (solid $\mathrm{CO}_{2}$ plus $35 \% \mathrm{TCA}$ ), and Coleman combination (70\% glycolic acid and 35\% TCA). Deep peels penetrate to the levels of the reticular dermis. ${ }^{58}$ The formulation of these peels contain croton oil and phenols in various concentrations. ${ }^{57,58} \mathrm{~A}$ study by Brody ${ }^{59}$ noted clinical improvement of skin laxity-attributed histologic depth achieved by medium-depth peels. The results of the study demonstrated that the depth of wounding from 3 consecutive applications of TCA led to greater epidermal hyperplasia and a more dense formation of dermal elastic fiber formation on histologic examination. Side effects noted in the study included transient erythema, edema, and erosions that resolved without scar formation at 30-day follow-up. ${ }^{59}$ Another study performed by Oresajo et $\mathrm{al}^{60}$ demonstrated that patients treated with either a chemical peel of $41 \%$ capryloyl salicylic acid or $30 \%$ glycolic acid led to notable reduction of fine lines/wrinkles vs baseline. Side effects noted included pruritus, erythema, increased skin sensitivity, epidermolysis, allergic and irritant contact dermatitis, and postinflammatory hyperpigmentation. ${ }^{60}$

\section{Skin Care}

Skin care products have been developed over the years and marketed to aid in the treatment of skin laxity. Some studied methods include photoprotection products, antioxidant-based products, and vitamin A products. Photoprotection plays a crucial role in the prevention of skin laxity. Unprotected sun exposure can induce damage to previously treated skin, leading to minimized or cancelled rejuvenation measures. ${ }^{61}$

Oxidation is a major contributor in the development of skin laxity. The skin naturally possesses endogenous antioxidant defense mechanisms that protect its cells from free radical damage. However, these mechanisms are reduced as skin ages and are further diminished with photodamage. Ascorbic acid is a collagen stimulator that is known to have antioxidant properties. In the appropriate formulations, topical vitamin $\mathrm{C}$ directly supplements the skin's antioxidant reservoir. ${ }^{61}$

The use of vitamin A, a retinoic acid, for treatment of skin laxity is based on its ability to improve the production of procollagen and elastic fiber components, resulting in the restoration of dermal matrix proteins. ${ }^{.1-65}$ Vitamin A in the skin plays a key role in the regulation and control of proliferation and differentiation of all major cell types found in the epidermis and dermis. ${ }^{61}$ Studies have shown that the long-term use of topical vitamin A improves fine and coarse wrinkling. ${ }^{65}$

\section{Final Thoughts}

Various technologies have been developed to provide clinically significant skin laxity reversal. Laser, RF, ultrasound, IPL, and topical therapies provide numerous options at our disposal. Although many devices are available, it is important to consider the desired outcome, cost, and adverse 
events when discussing therapeutic options for treating skin laxity (eTable). Patients should be advised that multiple treatment sessions over the course of months will likely be necessary. With the development of numerous technologies, we now have many options to offer our patients who desire minimally or noninvasive skin tightening.

\section{REFERENCES}

1. McCullough JL, Kelly KM. Prevention and treatment of skin aging. Ann NY Acad Sci. 2006;1067:323-331.

2. Yaar M. Clinical and histological features of intrinsic versus extrinsic skin aging. In: Gilchrest BA, Krutmann J, eds. Skin Aging. Berlin, Germany: Springer, Heidelberg; 2006:9-21.

3. Ramanadham SR, Costa CR, Narasimhan K, et al. Refining the anesthesia management of the face-lift patient: lessons learned from 1089 consecutive face lifts. Plast Reconstr Surg. 2015;135:723-730.

4. Gupta V, Winocour J, Shi H, et al. Preoperative risk factors and complication rates in facelift: analysis of 11,300 patients. Aesthet Surg J. 2016;36:1-13.

5. le Lous M, Flandin F, Herbage D, et al. Influence of collagen denaturation on the chemorheological properties of skin, assessed by differential scanning calorimetry and hydrothermal isometric tension measurement. Biochim Biophys Acta. 1982;717:295-300.

6. Ross EV, Yashar SS, Naseef GS, et al. A pilot study of in vivo immediate tissue contraction with $\mathrm{CO}_{2}$ skin laser resurfacing in a live farm pig. Dermatol Surg. 1999;25:851-856.

7. Arnoczky SP, Aksan A. Thermal modification of connective tissues: basic science considerations and clinical implications. J Am Acad Orthop Surg. 2000;8:305-313.

8. Hsu TS, Kaminer MS. The use of nonablative radiofrequency technology to tighten the lower face and neck. Semin Cutan Med Surg. 2003;22:115-123.

9. Alster TS. Cutaneous resurfacing with $\mathrm{CO}_{2}$ and erbium: YAG lasers: preoperative, intraoperative, and postoperative considerations. Plast Reconstr Surg. 1999;103:619-632; discussion 633-634.

10. Omi T, Numano $\mathrm{K}$. The role of the $\mathrm{CO}_{2}$ laser and fractional $\mathrm{CO}_{2}$ laser in dermatology. Laser Ther. 2014;23:49-60

11. Preissig J, Hamilton K, Markus R. Current laser resurfacing technologies: a review that delves beneath the surface. Semin Plast Surg. 2012;26:109-116.

12. Bernstein LJ, Kauvar AN, Grossman MC, et al. The short- and longterm side effects of carbon dioxide laser resurfacing. Dermatol Surg. 1997;23:519-525.

13. Nanni CA, Alster TS. Complications of carbon dioxide laser resurfacing. an evaluation of 500 patients. Dermatol Surg. 1998;24:315-320.

14. Ortiz AE, Tremaine AM, Zachary CB. Long-term efficacy of a fractional resurfacing device. Lasers Surg Med. 2010;42:168-170.

15. Rahman Z, MacFalls H, Jiang K, et al. Fractional deep dermal ablation induces tissue tightening. Lasers Surg Med. 2009;41:78-86

16. Graber EM, Tanzi EL, Alster TS. Side effects and complications of fractional laser photothermolysis: experience with 961 treatments. Dermatol Surg. 2008;34:301-305; discussion 305-307.

17. Fisher GH, Geronemus RG. Short-term side effects of fractional photothermolysis. Dermatol Surg. 2005;31:1245-1249.

18. Ortiz AE, Goldman MP, Fitzpatrick RE. Ablative $\mathrm{CO}_{2}$ lasers for skin tightening: traditional versus fractional. Dermatol Surg. 2014;40(suppl 12):S147-S151.

19. Geronemus RG. Fractional photothermolysis: current and future applications. Lasers Surg Med. 2006;38:169-176.

20. Tierney EP, Hanke CW, Petersen J. Ablative fractionated $\mathrm{CO}_{2}$ laser treatment of photoaging: a clinical and histologic study. Dermatol Surg. 2012;38:1777-1789.

21. Tierney EP, Hanke CW, Watkins L. Treatment of lower eyelid rhytids and laxity with ablative fractionated carbon-dioxide laser resurfacing: case series and review of the literature. J Am Acad Dermatol. 2011;64:730-740

22. Fife DJ, Fitzpatrick RE, Zachary CB. Complications of fractional $\mathrm{CO}_{2}$ laser resurfacing: four cases. Lasers Surg Med. 2009;41:179-184.
23. Metelitsa AI, Alster TS. Fractionated laser skin resurfacing treatment complications: a review. Dermatol Surg. 2010;36:299-306.

24. Miller L, Mishra V, Alsaad S, et al. Clinical evaluation of a non-ablative 1940 nm fractional laser. J Drugs Dermatol. 2014;13:1324-1329.

25. Alexiades-Armenakas M. Nonablative skin tightening with a variable depth heating 1310-nm wavelength laser in combination with surface cooling. J Drugs Dermatol. 2007;6:1096-1103.

26. Alster TS, Wanitphakdeedecha R. Improvement of postfractional laser erythema with light-emitting diode photomodulation. Dermatol Surg. 2009;35:813-815.

27. Fournier N, Lagarde JM, Turlier V, et al. A 35-month profilometric and clinical evaluation of non-ablative remodeling using a 1540-nm Er:glass laser. J Cosmet Laser Ther. 2004;6:126-130.

28. Hædersdal M, Moreau KER, Beyer DM, et al. Fractional nonablative $1540 \mathrm{~nm}$ laser resurfacing for thermal burn scars: a randomized controlled trial. Lasers Surg Med. 2009;41:189-195.

29. Lupton JR, Williams CM, Alster TS. Nonablative laser skin resurfacing using a $1540 \mathrm{~nm}$ erbium glass laser: a clinical and histologic analysis. Dermatol Surg. 2002;28:833-835.

30. Moody BR, McCarthy JE, Hruza GJ. Collagen remodeling after 585-nm pulsed dye laser irradiation: an ultrasonographic analysis. Dermatol Surg. 2003;29:997-999, discussion 999-1000.

31. Pollock H, Pollock TA. NLite laser: nonablative wrinkle reduction. Aesthet Surg J. 2001;21:371-372.

32. Burns JA. Thermage: monopolar radiofrequency. Aesthet Surg J. 2005;25:638-642

33. Weiss RA, Weiss MA, Munavelli G, et al. Monopolar radiofrequency facial tightening: a retrospective analysis of efficacy and safety in over 600 treatments. J Drugs Dermatol. 2006;5:707-712.

34. Sadick NS, MakinoY. Selective electro-thermolysis in aesthetic medicine: a review. Lasers Surg Med. 2004;34:91-97.

35. Alster TS, Lupton JR. Nonablative cutaneous remodeling using radiofrequency devices. Clin Dermatol. 2007;25:487-491.

36. Fitzpatrick R, Geronemus R, Goldberg D, et al. Multicenter study of noninvasive radiofrequency for periorbital tissue tightening. Lasers Surg Med. 2003;33:232-242.

37. Dover JS, Zelickson B, 14-Physician Multispecialty Consensus Panel. Results of a survey of 5,700 patient monopolar radiofrequency facial skin tightening treatments: assessment of a low-energy multiple-pass technique leading to a clinical end point algorithm. Dermatol Surg. 2007;33:900-907.

38. de Oliveira TC, Rocha SF, Ramos DG, et al. Effects of multipolar radiofrequency and pulsed electromagnetic field treatment for face and neck rejuvenation [published online March 8, 2017]. Dermatol Res Pract. doi:10.1155/2017/4146391.

39. Fabi SG. Noninvasive skin tightening: focus on new ultrasound techniques. Clin Cosmet Investig Dermatol. 2015;8:47-52.

40. Van Leenders GJ, Beerlage HP, Ruijter ET, et al. Histopathological changes associated with high intensity focused ultrasound (HIFU) treatment for localised adenocarcinoma of the prostate. J Clin Pathol. 2000;53:391-394.

41. Wulkan AJ, Fabi SG, Green JB. Microfocused ultrasound for facial photorejuvenation: a review. Facial Plast Surg. 2016;32:269-275.

42. MacGregor JL, Tanzi EL. Microfocused ultrasound for skin tightening. Semin Cutan Med Surg. 201332:18-25

43. Oni G, Hoxworth R, Teotia S, et al. Evaluation of a microfocused ultrasound system for improving skin laxity and tightening in the lower face. Aesthet Surg J. 2014;34:1099-1110.

44. Brobst RW, Ferguson M, Perkins SW. Noninvasive treatment of the neck. Facial Plast Surg North Am. 2014;22:191-202.

45. Alster TS, Tanzi EL. Noninvasive lifting of arm, thigh, and knee skin with transcutaneous intense focused ultrasound. Dermatol Surg. 2012;38:754-759.

46. Missel L. Prevention of potential adverse events associated with use of Ulthera device. Tech Bull. 2011;32:18-25.

47. Bove T, Zawada T, Serup J, et al. High-frequency (20-MHz) high-intensity focused ultrasound (HIFU) system for dermal intervention: preclinical evaluation in skin equivalents. Skin Res Technol. 2019;25:217-228.

CONTINUED ON PAGE 139 


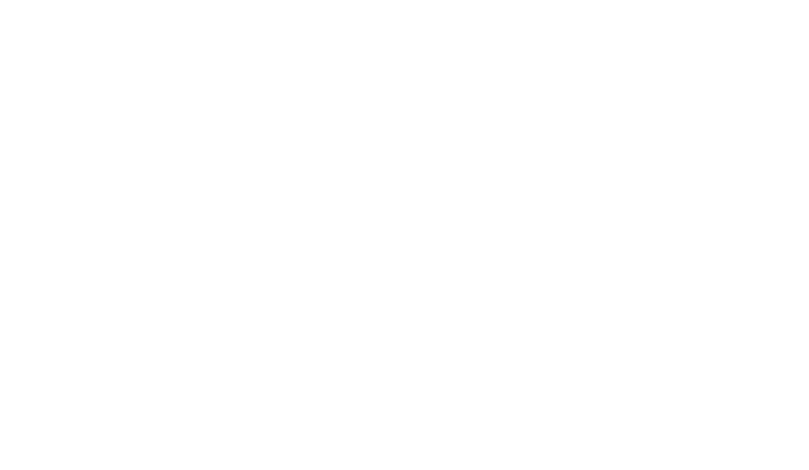

COSMETIC DERMATOLOGY

CONTINUED FROM PAGE 137

48. Raulin C, Greve B, Grema H. IPL technology: a review. Lasers Surg Med. 2003;32:78-87.

49. Anderson RR, Parrish JA. Selective photothermolysis: precise microsurgery by selective absorption of pulsed radiation. Science. 1983;220:524-527.

50. Faucz LL, Will SE, Rodrigues CJ, et al. Quantitative evaluation of collagen and elastic fibers after intense pulsed light treatment of mouse skin. Lasers Surg Med. 2018;50:644-650.

51. Goldberg DJ, Cutler KB. Nonablative treatment of rhytids with intense pulsed light. Lasers Surg Med. 2000;26:196-200.

52. Li Y-H, Wu Y, Chen JZ, et al. Application of a new intense pulsed light device in the treatment of photoaging skin in Asian patients. Dermatol Surg. 2008;34:1459-1464.

53. Shin J-W, Lee D-H, Choi S-Y, et al. Objective and non-invasive evaluation of photorejuvenation effect with intense pulsed light treatment in Asian skin. J Eur Acad Dermatol Venereol. 2011; 25:516-522.

54. Weiss RA, Weiss MA, Beasley KL. Rejuvenation of photoaged skin: 5 years results with intense pulsed light of the face, neck, and chest. Dermatol Surg. 2002;28:1115-1119.

55. Lee KC, Wambier CG, Soon SL, et al. Basic chemical peeling: superficial and medium-depth peels. J Am Acad Dermatol. 2019;81:313-324.

56. Brody HJ. Do chemical peels tighten the skin? Dermatol Surg. 2014;40(suppl):S129-S133.

57. Landau M. Chemical peels. Clin Dermatol. 2008;26:200-208.
58. Meaike JD, Agrawal N, Chang D, et al. Noninvasive facial rejuvenation. part 3: physician-directed-lasers, chemical peels, and other noninvasive modalities. Semin Plast Surg. 2016;30:143-150.

59. Brody HJ.Variations and comparisons in medium-depth chemical peeling. J Dermatol Surg Oncol. 1989;15:953-963.

60. Oresajo C, Yatskayer M, Hansenne I. Clinical tolerance and efficacy of capryloyl salicylic acid peel compared to a glycolic acid peel in subjects with fine lines/wrinkles and hyperpigmented skin. J Cosmet Dermatol. 2008;7:259-262.

61. Aust MC, Fernandes D, Kolokythas P, et al. Percutaneous collagen induction therapy: an alternative treatment for scars, wrinkles, and skin laxity. Plast Reconstr Surg. 2008;121:1421-1429.

62. Griffiths C. The role of retinoids in the prevention and repair of aged and photoaged skin. Clin Exp Dermatol. 2001;26:613-618.

63. Darlenski R, Surber C, Fluhr J. Topical retinoids in the management of photodamaged skin: from theory to evidence-based practical approach. Br J Dermatol. 2010;163:1157-1165.

64. Kang S, Bergfeld W, Gottlieb AB, et al. Long-term efficacy and safety of tretinoin emollient cream $0.05 \%$ in the treatment of photodamaged facial skin: a two-year, randomized, placebo-controlled trial. Am J Clin Dermatol. 2005;6:245-253

65. Riahi RR, Bush AE, Cohen PR. Topical retinoids: therapeutic mechanisms in the treatment of photodamaged skin. Am J Clin Dermatol. 2016;17:265-276.

66. American Society of Plastic Surgeons. Average surgeon/physician fees. https://www.plasticsurgery.org/documents/News/Statistics/2019 /cosmetic-procedures-average-cost-2019.pdf. Accessed August 24, 2020. 


\section{APPENDIX}

\section{eTABLE. Factors to Consider When Evaluating Treatments for Skin Laxity}

\begin{tabular}{|c|c|c|c|c|c|}
\hline Treatment & $\begin{array}{l}\text { General } \\
\text { Cost, }^{66, a} \text { \$ }\end{array}$ & Efficacy & $\begin{array}{l}\text { Frequency of } \\
\text { Treatments }\end{array}$ & Healing Time & Potential Side Effects \\
\hline Laser therapy ${ }^{20,24}$ & $\begin{array}{l}\text { Ablative: } \\
\text { 1963; } \\
\text { nonablative: } \\
1201\end{array}$ & $\begin{array}{l}\text { Ablative: } 56 \%- \\
65.3 \% \text { at } 6 \text { mo } \\
\text { posttreatment; } \\
\text { nonablative: } \\
8.9 \%-11 \% \text { in } \\
\text { skin laxity } 3 \text { mo } \\
\text { posttreatment }\end{array}$ & $\begin{array}{l}\text { Ablative: single } \\
\text { treatment; nonablative: } \\
3 \text { full-face treatments } \\
\text { 4-6 wk apart }\end{array}$ & $\begin{array}{l}\text { Ablative: } \\
1-10 \text { d } \\
\text { following last } \\
\text { treatment; } \\
\text { nonablative: } \\
\text { minimal }\end{array}$ & $\begin{array}{l}\text { Ablative: } \\
\text { hyperpigmentation, } \\
\text { erythema, edema, acne, } \\
\text { infection, scarring; } \\
\text { nonablative: transient } \\
\text { erythema, transient edema, } \\
\text { transient } \mathrm{PIH} \text {, herpes } \\
\text { reactivation }\end{array}$ \\
\hline Radiofrequency ${ }^{36}$ & 2134 & $\begin{array}{l}28.9 \%-54 \% \\
\text { improvement } \\
\text { of the entire } \\
\text { treatment } \\
\text { area at } 6-m o \\
\text { follow-up }\end{array}$ & Single treatment pass & $\begin{array}{l}\text { No recovery } \\
\text { time }\end{array}$ & $\begin{array}{l}\text { Erythema, edema, } \\
\text { blistering, bruising, } \\
\text { burns, skin indentations, } \\
\text { subcutaneous fat loss, } \\
\text { permanent scarring, } \\
\text { changes to pigmentation, } \\
\text { open sores, and infections }\end{array}$ \\
\hline Ultrasound ${ }^{43}$ & 2134 & $\begin{array}{l}63.6 \% \text { at } 90 \mathrm{~d} \\
\text { posttreatment }\end{array}$ & $\begin{array}{l}\text { Single treatment with } \\
\text { double passes over } \\
\text { targeted areas }\end{array}$ & $\begin{array}{l}\text { No recovery } \\
\text { time }\end{array}$ & $\begin{array}{l}\text { Transient purpura, transient } \\
\text { edema, transient PIH; } \\
\text { serious complications } \\
\text { are rare and include } \\
\text { development of palpable } \\
\text { subcutaneous nodules and } \\
\text { motor nerve paresis }\end{array}$ \\
\hline $\begin{array}{l}\text { Intense pulsed } \\
\text { light therapy }{ }^{11-54}\end{array}$ & 406 & $\begin{array}{l}\text { Incongruent } \\
\text { results }\end{array}$ & $\begin{array}{l}4-6 \text { treatments at } \\
3-w k \text { intervals }\end{array}$ & $\begin{array}{l}\text { No recovery } \\
\text { time }\end{array}$ & $\begin{array}{l}\text { Transient pain, swelling, } \\
\text { and erythema, along with } \\
\text { rare instances of blisters } \\
\text { and crusting }\end{array}$ \\
\hline Chemical peels ${ }^{60}$ & 644 per & $\begin{array}{l}41 \% \text { of capryloyl } \\
\text { salicylic acid- } \\
\text { treated and } \\
30 \% \text { of glycolic } \\
\text { acid-treated } \\
\text { patients } \\
\text { demonstrated } \\
\text { notable reduction } \\
\text { of fine lines/ } \\
\text { wrinkles vs } \\
\text { baseline }\end{array}$ & $\begin{array}{l}\text { Biweekly product } \\
\text { application of either } \\
\text { of } 2 \text { peels for } 12 \text { wk }\end{array}$ & $\begin{array}{l}1-7 \mathrm{~d} \text { (varies } \\
\text { with depth } \\
\text { of peel) }\end{array}$ & $\begin{array}{l}\text { Pruritus, erythema, } \\
\text { increased skin sensitivity, } \\
\text { epidermolysis, allergic } \\
\text { and irritant contact } \\
\text { dermatitis, PIH }\end{array}$ \\
\hline Skin care & $\begin{array}{l}\text { Variable, } \\
\text { depending } \\
\text { on products }\end{array}$ & $\begin{array}{l}\text { Prevention } \\
\text { of laxity } \\
\text { development }\end{array}$ & Daily application & None & Adverse allergic reactions \\
\hline
\end{tabular}

Abbreviation: $\mathrm{PIH}$, postinflammatory hyperpigmentation.

avaries with treatment area, geographic location, and physician practice. 